\title{
Virtuous suffering and the predicament of being handicapped. Towards a theology of the 'disabled God puffing in a wheelchair'
}

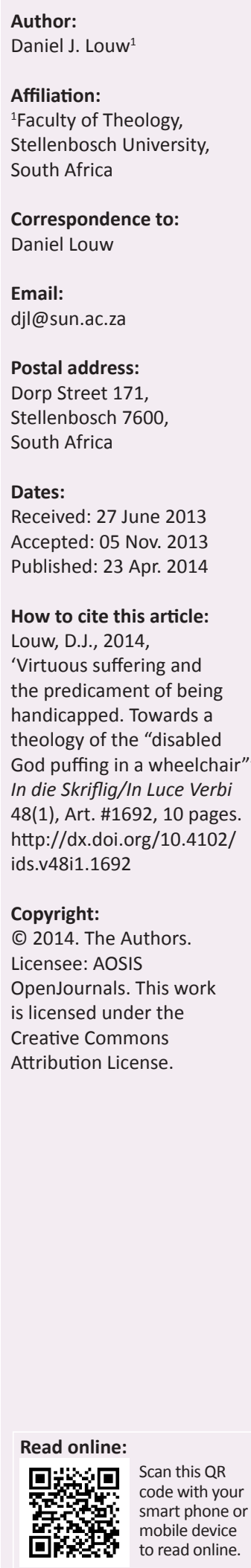

The reality of disablement, being handicapped and physical disfigurement, opens up anew the theological debate regarding God-images in human suffering. It is argued that the Hellenistic understanding of the power of God, God as a pantokrator [Almighty], presupposes the immutability of an apathetic God. In terms of the logic of a cause-effect paradigm, God becomes the deterministic principle behind human suffering. With reference to a theologia crucis [theology of the Cross], the paradigm of theopaschitic theology proposes a pathetic understanding of God. Weakness and vulnerability (astheneia) describes an authentic identification of God with human suffering. Forsakenness (derelictio) reframes power as compassionate weakness or vulnerability and divine disability. The disabled God is, in terms of the New Testament a connection between divine compassion and human predicament (ta splanchna), the passionate God. Bowel categories make it possible to speak of the 'puffing God in the wheelchair'. A theology of the cross should be supplemented by a theology of ability (theologia resurrectionis). The resurrection introduces the spiritual ability parrhesia - the transformation of the weakness of suffering into the fortigenitics of hope.

Lyding tussen lot en deug binne die dilemma van gestremdheid. Die onwikkeling van 'n teologie van die 'gestremde God, hygend in 'n rolstoel'. Die gegewendheid en realiteit van verskillende vorme van gestremdheid onderstreep menslike weerloosheid en magteloosheid. Vir gelowiges wat worstel met die vraag na sin in lyding, roep dit onder andere die vraag op na die verband tussen lyding en die almag en krag van God. Die basiese argument is dat die Hellenistiese konsep en paradigma van die mag van God, God as pantokrator, die starre onbeweeglikheid van 'n apatiese God voorveronderstel. Met behulp van die oorsaakgevolg skema van denke, word God, in terme van die menslike logika, 'n deterministiese kousaliteitsbeginsel en verklaringsmeganisme. Met behulp van ' $n$ teopasgitiese hermeneutiek binne die raamwerk van 'n kruisteologie, word aandag gegee aan die opsie van 'n lydende en meelydende God (die passie van God). Die swakheid en weerloosheid van God (astheneia) beskryf die egtheid en integriteit van God in terme van 'n wesenlike identifikasie met die lyding van mense. Verlatenheid (derelictio) transformeer die populêre, dogmatiese siening van almags-determinisme in die sensitiewe paradigma van weerlose medelye. 'n Teologie van die 'gestremde God' word ontwikkel in die lig van die teologiese implikasies van ta splanchna op 'n eksistensiële Godsverstaan. 'n Tipe erbarmingsteologie ('binnegoed' of dermteologie) word ontwikkel wat help om die metafoor van 'n 'gestremde God, hygend in 'n rolstoel' pastoraal te verstaan. Met die oog op die omvattende verstaan van hoop, moet 'n kruisteologie aangevul word met ' $n$ opstandingsteologie. Die uitwerking van troos op mense met gestremdheid is parrhēsia: die moed om te lewe.

\section{Is there place for disability within the realm of Christian spirituality and pastoral theology?}

In a very recent publication on the plight to connect the traditional understanding of pastoral care as cura animarum [the cure of souls] to life experiences, Doris Nauer (2010:70) points out that the credibility of pastoral caregiving (Glaubwürdige Seelsorge) is closely connected to the theological question regarding the link between images of God and our human experience of suffering, isolation, loneliness, helplessness and hopelessness. Pastoral theology is deeply involved in the existential and spiritual experience of human beings: in their predicament and suffering, it seems as if God is a distanced and remote entity (Nauer ibid:83). Caregiving and spiritual direction should therefore give more attention to life issues - and very specifically, questions regarding the meaning and purpose of life (Sperry 2002:15) and how this spiritual realm is connected to an appropriate understanding of God and the power of God. In more Gestalt-terminology, caregiving 
is a form of networking. It connects the vital awareness of an organism with different transpersonal structures (Knights 2001:1-4) that refers to 'meaning giving'. Within the tradition of 'wisdom-thinking' (Schipani 2003) of the Old Testament, the challenge in pastoral care is to nurture a kind of prudence (Pr 8:5) that deals with the presence of God within the existential realities of life - a kind of wisdom and faith (Miller-McLemore 2006) that incorporates the 'landscapes of the human soul', namely the shadows of death, dying, doubt and injustice (Louw 2012:27). Cura animarum is, in terms of wisdom-thinking and spiritual direction (Leech 1986), in fact cura vitae [the healing of life] (Louw 2008:11).

From an existential point of view, one can say that life is demarcated by limitation, impairment, ailment, disease, obstruction, disaster, death and dying. Life is never complete. Human beings are actually 'handicapped beings': we are handicapped due to our vulnerability and mortality. Often in life the 'why' question is being posed. This question becomes more painful when one is faced with unexpected events of destruction and loss. When the loss is physical, for example in cases of physical disabilities, the 'meaning' question (Wong 2012:3-7) is often intertwined with the notion of undeserved suffering. Hence the question follows regarding the connection between human disability, experiences of being handicapped, human suffering, the human quest for meaning and the challenge it put before Christian spirituality, our God-images and the notion of the power, and compassion of God. Disability and handicap are variants of what Saunders (2010:6) calls 'spiritual suffering'.

Kool (2002:30-31) very aptly points out that being handicapped entails more than physical limitation. It is a cultural entity and social qualification too. It is closely connected to the spiritual realm of life. Handicap is not a fixed entity in the person, but the result of the mutual interaction between the person and his or her perception of being handicapped as well as his or her framework of life (convictions and commitments). One can say that handicap, disability, illness and suffering are all categories pointing to hermeneutics - thus the attempt to opt for a literature approach and critical assessment of sources within the methodology of hermeneutics (i.e. the attempt to link texts to contexts and vice versa).

As a theological problem, handicap and disability touch the fibre of the Christian faith, namely our understanding of God and his power. Thus the question follows: Is there any place for a constructive understanding of human disability within theology and a Christian spiritual understanding of our being human? This question actually deals with the very characteristics of God. It touches the core and heart of a Christian anthropology. It questions the basic theological and undergirding principles in pastoral caregiving, namely the notions of comfort and compassion (Louw 2000:73-117) and its connection to a theological understanding of the compassion and mercy of God (Davies 2003).

The following slogan by Oscar Pistorius (Coetzee 2011), the athlete with physical disability and so-called 'blade runner', challenges traditional theodicy and the human quest for meaning: 'You are not disabled by the disabilities you have; you are abled by the abilities you have.'

Is it possible to design a pastoral theology of 'human ability', despite the limitations of various forms of disability? With regard to physical handicaps and mental retardation, what is the theological option to toy with the notion of a 'disabled God'?

\section{The theistic God as Deus ex machina}

Many traditional models in orthodox theology respond most of the times to the crisis of unexpected and tragic life events with a cause-and-effect model of interpretation. Behind every crisis or form of suffering, the theological challenge is to link events with the will and power of God. The notion of an omnipotent and impassable deus ex machina [god from the machine] has been introduced to provide a solution to worldly distress (Schaab 2011:12).

Already in 1963, J.A.T Robinson warned against theism and a supranaturalist worldview. He pointed out that instead of the deus ex machina concept, the Bible directs God to the powerlessness and suffering of God: '[O]nly a suffering God can help' (Robinson 1963:39).

However, power (even the power of God) is most of the times defined as causative, domination and control (Pasewark 1993:2). This understanding of power always presents the need to defend the notion of God's omnipotence on philosophical and theological grounds, and for reasons of religious life.

The Confession of Faith (Belgic Confession) starts with the notion of power as the creation, preservation and government of the universe (Psalter Hymnal 1959:3). God as Father (Psalter Hymnal ibid):

... watches over us with paternal care, keeping all creatures so under his power that not a hair of our head (for they are all numbered), nor a sparrow can fall to the ground without the will of our Father [...] and not one of them falls apart from your father's will. (p. 8)

Although the word will is not mentioned in the Greek text of Matthew 10:29 (it literally says 'without our Father'), the interpreters read 'will of the Father' into the text in order to 'save' God as an explanatory principle behind tragic events. In the background of the religious mind, God determines everything in a cause-and-effect manner so that the will of God should at least equal divine power. Divine power is then interpreted in terms of cause (first principle) and governance (strength), and not in terms of care and compassion (vulnerability).

The challenge to the human mind in suffering and feelings of helplessness and severe pain is to reason back to a possible cause or logic explanation. The logos or explanatory principle is then tagged as the will of God. In this respect, God functions as a kind of deus ex machina. The will of God is then introduced as part of an eternal plan and fixed divine council - thus the notion of the immutability of God. 
According to Hall (1993:52), the notion of an immutable God must certainly be traced to the Greek side of our heritage. It was introduced to guard the triune God from kinds of passionate involvement that reduced the popular gods of the ancient world to personifications and caricatures of human follies (Hall ibid:52). Thus follows Hall's hypothesis (ibid):

The Christian doctrine of God has tended to accentuate the aspects of transcendence and power, as befits a patriarchally conceived deity in the service of the empire; but in doing so it has severely jeopardized the essence of God testified to in Holy scripture, and has risked confining belief in God to contexts amenable to 'positive religion'. (p. 92)

Within the framework of the omniscience of God, life events were experienced as a fixed plan or rational schedule. The concept of comfort was closely linked to the firm and immovable will of God. With reference to catastrophes, believers often experience helplessness and then respond with the saying that man proposes, but God disposes. A kind, stoic attitude develops, resulting in a fatalistic life stance and apathetic approach to the so-called 'undeserved forms' of suffering.

The stoic, monistic worldview attempts to reconcile the course of the world (fatum) with God's providence (pronoia). This gives rise to a cosmodicy - a justification of the given world as an appearance and manifestation of the divine reason. The world's imperfection is necessary in the light of the coming perfection. The evil that lies concealed in affective bodily needs and matter, presents a challenge to human freedom of will. This challenge can be overcome by an apathetic lifestyle. Apathy gives rise to an ethic of patience and neutrality towards suffering in order to bring about self-sufficiency. Within this rational teleology, suffering serves as a means of bringing a person to the perfection of self-sufficiency.

The outcome of this deterministic and very passive approach is fatalism: qua sera, sera [whatever will be, will be]. Divine omnipotence became a case of 'giving to God that which belongs exclusively to Caesar' (Pittenger quoted in Hall 1993:54). With the concept of a powerful omnipotent deity, theology wanted to uphold the image of a strong and potent God, fully in control of every second of life. However, if God initiates every tragedy, pain and all forms of suffering and disfigurement, what is then the meaning of the compassion of God? Or is it indeed the notion of compassion that can transform the immutability of an iron God into the passion of a disabled and co-suffering God?

\section{The predicament of being handicapped and disabled}

A very recent publication by Claassens, Swartz and Hansen (2013) underlines the predicament regarding disability, the human quest for meaning and dignity, and a theological approach to human impairment. The authors underline the importance of the role of theology to promote a more sensitive approach to disability within the public sphere of life.
The World Health Organization describes disability as an impairment of some biological, physical or psychological origin that causes an activity limitation or inability to function in some usual way which can vary in different contexts - a participation restriction, affecting involvement in life situations (Gaventa 2012:292). However, the important challenge to pastoral caregivers is to probe into the realm of presuppositions, prejudice, worldviews and attitudes (Gaventa ibid:292): '[W] hat we think about the impairment and functional limitation - our assumptions, values, and attitudes - is often the bigger "handicap".'

Within the current projection of 'healthism' in film and the social media, it is indeed difficult to detect what is meant by disability. As Reynolds (2008) states:

One prominent way that consumerism is disabling is in its promotion of youthful attractiveness and vitality. Multiple industries are supported by the obsession with youthfulness, connected up with the ideals of efficiency and novelty. The young are physiologically and developmentally fresh, vital, mobile, adaptive, eager, innovative, and adventurous. (p. 96)

Kool (2002:30-31) points out that the classification of being handicapped is, from a social perspective, a functional issue due to restrictions in terms of communication, relations and movement. The person in him- or herself is not a handicapped being. Handicap is not a fixed entity in the person, but the result of the mutual interaction between the person and his or her handicap, and the structural and social environment. One should therefore rather refer to persons 'with a handicap' than to 'handicapped persons'. It all depends on the assessment from the environment and the others' reactions. Handicap entails more than physical limitation. It is also a cultural entity and social qualification.

The same argument can be used in the case of disabilities. Eiesland (1994:24) argues that people with disabilities are distinguished from others - not because of their shared physical, psychological or emotional traits, but because 'temporarily able-bodied' persons single them out for differential treatment. Often this approach leads to the impression that, due to physical impairments, disabled people are not merely different, but classified as 'abnormal'. This leads to a common set of stigmatising values and arrangements that actually work against the person with disabilities.

Eiesland (1994:27) draws specific attention to terminology in this regard. 'Impairment' refers to an abnormality or loss of physiological form or function. 'Disability' describes the consequences of the impairment that is an inability to perform some task or activity considered necessary within a social environment. 'Handicap' generally denotes a social disadvantage that results from an impairment or disability. Impairment does not necessarily result in a disability and a disability does not need to be a handicap.

Persons with disabilities are therefore characterised as a minority group, shaped primarily by exclusion - hence the importance of accessibility as a social-symbolic, physical 
and legal inclusion in common life. Physical disabilities also challenge the God-image which theology applies to relate irreversible impairment to the will and omnipotence (power) of God (Louw 2000:45-73). Is it possible to replace deterministic God-images with more compassionate Godimages in order to develop a theology of compassion and comfort that can empower people with disabilities? How can theology contribute to a more pastoral and sensitive approach to disabilities in order to convey a sense of human dignity? Can a theology of compassion contribute to processes of destigmatisation?

\section{The sin-disability conflation in theology}

Spiritual and religious perspectives should, theologically speaking, also be questioned and rethought. A good example in this regard is the sin-disability conflation. Eiesland (1994:70) points out that a persistent view in the Christian tradition has been that disability denotes an unusual relationship with God and that the person with disabilities is either divinely blessed or damned: the spiritual superhero or the defiled evildoer. For example, a unilateral and biased exegesis is evident in several biblical texts (e.g. Lv 21:17-23) that prohibited people with disabilities and physical handicaps from entering the most holy place in the temple. The sin-disability paradigm also functions in John 9:1-3. When Jesus encountered a man born blind, his disciples asked whether the man or his parents sinned. The presupposition is that there should be an explanation for being handicapped in terms of the existing cause-effect schema of interpretation. This deterministic schema raises the issue of whether physical disability is a travesty of the divine image and an inherent desecration of all things holy.

Despite the tendency to assess our 'being handicapped' as pathology, it will be argued that disability and vulnerability should not be viewed as 'abnormal' (deterministic tragedy), but as 'normal' (existential reality). It is normal, because life in itself is embedded in a network of different forms of vulnerability and limitations or impairments. Disability should therefore be assessed as a normal category of human life; as an ontological quality of being. As Reynolds (2008) puts it:

Disability is an unavoidable part of all human agencies. Different individuals, 'disabled in different ways and degrees, can have their own peculiar talents and possibilities and their own difficulties'. While some people may struggle with a higher degree of disability than others, all human beings are disabled to some degree - often unpredictably and at different periods of our lives - from infancy to old age. (p. 106)

It is the contention of Reynolds (2008:33) that disability is not about others and 'them'. It is about us and the skewed paradigms and perceptions of a so-called 'healthy' and 'normal' society. Reynolds (ibid) thus advocates for a more holistic definition of disability beyond the categories of a medical model (an impairment that needs to be healed by an aggressive intervention). Disability is a term naming that interstice where (1) restrictions due to an involuntary bodily impairment, (2) social role expectations, and (3) external physical or social obstructions come together in a way that (4) pre-empts an intent participation in normal life. With reference to the spiritual dimension at stake, one could say that disability becomes a theological issue when (5) the involuntary bodily impairment is justified by a theology that links the will of God as a principle cause or explanation for the impairment. Disability then becomes a spiritual flaw that labels the impairment as a curse or punishment, and so becomes a problem of an inclusive theodicy - the attempt to link the providence of God to suffering and vulnerability through the logic of rational reasoning.

If it is true that disability is a feature of our 'being-in-thisworld', and if it is true that a person with disabilities gives others the precious insight into the woundedness and weakness of human life (Moltmann quoted in Reynolds 2008:117), what then is the impact of vulnerability and disability on the very being of God? How does disability and being handicapped change the theological categories that we apply to demonstrate divine compassion?

\section{The affliction of virtuous suffering}

Another theological paradigm that adds to the marginalisation and stigmatisation of suffering people is what can be called virtuous suffering (Eiesland 1994:72). The account of the apostle Paul's 'thorn in the flesh' as sign of divine grace (2 Cor 12:7-10), has been influential in supporting what Eiesland (1994) calls, a Christian theology of virtuous suffering. Righteous submission to divine testing is upheld as a praiseworthy disposition for Christian disciples. Impairments become signs of divine election by which the righteous are purified and perfected through painful trials. Disability is represented as a temporary affliction that must be endured to gain heavenly rewards.

Within the context of the traditional theodicy discourse, the view that all forms of suffering or human impairment should be endured in order to discover something good or to attain spiritual growth, is called the gubernatio approach. Suffering and impairment are viewed teleologically as a process or means of attaining some or other higher goal (gubernatio). Suffering then becomes a kind of virtue.

Within the Irenaeus tradition, there is the understanding that God created a world that included evil with a view to the end goal of a perfect world. In his work Evil and the God of Love, Hick (1966) argues that the Fall is a necessary feature of all creatureliness. Humans are in the process of becoming perfect beings who conform to God's original purpose. Human autonomy must develop into goodness, thus necessitating the possibility of both good and evil. There is an intellectual gap between God and humans which affords humans the space to grow towards perfection. Evil serves a purpose in this process: it is necessary for one's freedom and ultimate goodness. The conflict between good and evil will be resolved eschatologically in the eternal life. In the meantime, to endure 
suffering with courage is a means to prove the strength of one's faith. To suffer is then becoming a kind of masochistic prerequisite for attaining 'holiness'. The implication of such an understanding of suffering is that sanctification determines justification - the imperative (ought) the indicative (being functions) and not vice versa. The further implication is that determinism and fatalism prevail.

The background of many theodicy theories is often the presupposition that the physical world is a created order that mirrors a divine archetype reckoned to be intrinsically 'good'. The world and creation reflects in itself a divine intention. 'Normalcy' is thereby given a theological credence. Tragedy and abnormalities are perceived as inverse reflections of God's purpose - a tragic mark of something gone wrong (Reynolds 2008):

Disability quickly becomes a sign of imperfection, a flaw in God's good order, something to be undone. And because of this, theodicy questions foster an understanding of disability that leads down an erroneous path. (p. 30)

Eiesland (1994) argues that virtuous suffering encourages passivity and resignation, and has institutionalised depression and helplessness as an appropriate response to 'divine testing'. He (Eiesland 1994) states that:

... the theology of virtuous suffering has encouraged persons with disabilities to acquiesce to social barriers as a sign of obedience to God and to internalise second-class status inside and outside the church. (p. 73)

According to Eiesland (1994:73-74), the biblical theme of charitable giving has also shaped patterns of interaction between able-bodied individuals and those with disabilities. Instead of religious inclusion and meeting the requirement of justice, these practices often lead to marginalisation. The practice of individualistic charity and healing often neglect the social and political needs of people with disabilities, leading to social exclusion. The point is that believers often argue that if one provides in the physical needs of people and if the society or community are good to disabled people, our charity is enough. 'In short, through such actions, the Christian church became a prime facilitator of charitable practices that segregated people with disabilities' (Eiesland ibid:74). Charitable giving becomes an excuse not to become involved in matters of human dignity and the deep-seated spiritual needs regarding justice and the human quest for meaning.

However, to overcome stigmatisation more than charity is needed. The question is about the character of our involvement. How are we engaged with the being functions of disabled people in order to be with them in such a way that they discover meaning in life and are empowered to live a dignified life? What is the quality of our compassion? What is the intention behind the charitable act?

Furthermore, can we minister a God-image that is linked to the predicament of being handicapped and disabled - a God-image that reveal not an apathetic God, but a pathetic
God who is in fact identified with all kinds of impairment and disability? In terms of the vulnerability or weakness (astheneia) of a crucified God (theologia crucis), is it even possible to speak of a 'disfigured' and 'handicapped' God?

\section{Theopaschitic theology: The weak (astheneia) and disabled God}

Paul argues for the weakness (astheneia) of God in terms of a theology of the cross (1 Cor 1:25). The cross could then be viewed as a theological reflection and a fundamental critique - even a protest and lament - on woundedness, weakness, disfigurement, ailment, vulnerability, marginalisation and stigmatisation. Hence, with reference to the link between disability, human suffering and the presence of God in suffering, the theological question follows: Is it possible to speak of the 'suffering God'?

This question refers to the act that in every era, the ubiquity of pain, suffering, disfigurement and death, endemic within the cosmos and endured by the creatures, has provoked poignant and perplexing questions (Schaab 2011:3). The attempt to fathom and reconcile painful experiences of suffering with belief in an all-loving and all-powerful God, has led to several attempts by theologians to design a theodicy and to shore up the delicate balance between the experience of cosmic tragedy and the belief in an all-good God (Schaab ibid:3-4). The point is that the reality of suffering has persistently impelled theological debate concerning the relationship of God to suffering (Schaab ibid:11). The conceivability of the suffering of God has traditionally been called the theopaschitic model.

The theopaschitic approach clearly links God with suffering. The cross completes this link and this reveals God as a 'pathetic' being. He is the 'suffering God'. In Het theopaschitisme, Feitsma (1956:143) calls this form of theopaschitism (redefining God's being in terms of suffering) the most ultimate expression in theology of what is meant by God's compassion.

In the effort to identify God with human suffering, theopaschitism became the theory or doctrine by which theology tries to construe a more existential and passionate approach to our understanding of God's presence within the reality of human suffering. The issue of identification with the predicament of our being human (injustice, poverty, stigmatisation, discrimination, stereotyping, illness, violence, the abuse of power, tsunamis, catastrophes) has become of the uttermost importance for a new understanding of the meaning of Christian hope and spiritual healing.

\section{Transcendence versus condescendence}

A theopaschitic approach, which leans strongly towards empathy, acceptance and sympathetic understanding in pastoral care, has been welcomed by those theologians who want to reframe paradigms regarding God's will (Moltmann 1972). No longer is God seen as static and absolute, but 
rather as dynamic, thereby opening up the future for human existence. Although the pathos concept suggests evidence of God's genuine involvement in suffering, there is a danger that the distinction between the passio Dei [divine passion] and the passio hominum [suffering of human beings] can easily fall away. God's sovereignty (transcendence) can easily be sacrificed by an overemphasis on God's enfleshment and identification (condescension).

Inbody (1997:140) captures this problem very aptly when he argues that, in our attempt to rethink the meaning of divine power, two things can happen:

1. Our God-image can become 'too small', or 'too big'. If God can only empathise with the suffering of the world, but can do nothing about it, God is too small. If God is identified with nature and can do nothing more than what positivists mean by natural law, God is too small. If God is identified with human capacities, abilities, creativity or human ideals, then God is minimalised.

2. On the other hand, if God is identified with omnipotent power, as the kind of power that can do 'just anything', God is too big. When a theistic notion of divine omnipotence portrays God's kingdom in terms of an empire, he becomes too militant and strong. God is then merely a Hellenistic 'pantokrator', that is an all-powerful God who can do everything and is the instigator of all modes of human suffering.

It becomes clear that suffering, as a theological issue, creates a tension: the tension between God's sovereignty (power) and his solidarity (pathos). An overemphasis of God's identification with suffering presents the danger that God's immanent experience is traded for his sovereignty. On the other hand, a theology that emphasises God's sovereignty and his punishment, thereby distancing God from suffering, incurs the danger of presenting God as alienated from reality.

\section{Theologia crucis: The connection between human suffering and God's being}

For the advocates of a theologia crucis, the cross of Christ becomes the proof that God is not unyielding and sadistic, but is deeply affected by evil. God identifies with suffering and is not apathetic towards it. In his sympathetic involvement with suffering, God shows his compassion, thereby proclaiming that suffering is directly opposed to his will.

In section 21 of his Heidelberg disputations, Luther (1518) declares that, whilst a theology of glory speaks well of the bad and calls the bad good, it is the theology of the cross that describes essential reality and perceives being in terms of its essential characteristics (Theologus gloriae dicit malum bonum et bonum malum, Theologus crucis dicit id quod res est). In section 20, Luther ( $i b i d$ ) says that the visible and the (future) aspects not yet revealed concerning the presence of God should be perceived from the perspective of suffering and the cross (Sed qui visibilia et posteriora Dei per passiones et crucem conspect intelligit). The cross becomes a resource of comprehension and understanding. Not only does Luther defend himself against any natural or self-glorifying theology in these sections, he also proclaims the pastoral dimension of the cross, namely that God relates to human suffering.

Von Loewenich (1976:18) interprets Luther's disputation as an indication that the cross is not merely a subject of theological discussion, but constitutes in itself a definite theology. The cross does not merely play a role in our assurance of salvation. It is the very epicentre of all theological statements. The cross of Christ and the cross of the Christian belong together. The cross of Christ reveals the nature (the how) of the relationship between God and human beings.

In the very beginnings of the Christian era, Ignatius of Antioch spoke of God's suffering. However, according to Leech (1985:301), the crucial step towards understanding the identification of Christ's pain with God's pain was the formula of the Council of Ephesus of 431 concerning the divine motherhood of Mary. Ephesus proclaimed that Mary was Theotokos - the God-bearer, the mother of God. She was the mother of God's flesh. It was this assertion that, after centuries of reflection, led to the theopaschitic formula - the claim that God had suffered in the flesh. For, as Gregory of Nazianen (Leech ibid:301) had stressed: '[W]e need a God made flesh and put to death in order that we could live again.' Gregory speaks of 'the blood of God' and of 'the crucified God' - terms that were later adopted by Luther, who speaks of the Deus crucifixus.

For Luther, the sole authentic locus of our human knowledge of God is the cross of Christ in which God is to be found revealed and yet, paradoxically, hidden in that revelation (McGrath 1985:149, 161-175). God is revealed in the passiones et crucem - yet he is hidden in this very revelation. God's divinity is revealed in the very things that human wisdom regards as the antithesis of deity (such as weakness, folly and humility) - God is revealed in the humility and shame of the cross. Luther's argumentation implies the fundamental insight that the proper disposition for justification is humility. The righteousness that God demands is not 'good works', but the humilitas fidei [humility of faith]. Sinners can only be justified when, in total humiliation, they cry out to God for grace. Before grace can be granted to sinners, they must be forced to admit the total inadequacy of their own soteriological resources and turn to God in emptiness and prayer (see McGrath ibid:153).

At the cross God is hidden (Deus absconditus). Because of our existential predicament (Anfechtung), we are forced into a state of absolute despair. However, in faith we reach out to this hidden God. Thus, faith becomes a kind of existential understanding of this dialectic: to recognise oneself as a guilty criminal before God's wrath and then to flee to this very God, although apparently absent (hidden at the cross). Through this realisation, one is moved to flee to God against God (ad deum contra Deum; McGrath 1985:173). Anfechtung then becomes a kind of vehicle to connect faith to God. 
The German term Anfechtung describes a state of hopelessness and helplessness which has strong affinities with the concept anxiety (Angst). The terms that Luther use when discussing Anfechtung (see McGrath 1985:170) illuminate the various aspects of the concept. It is a form of temptation (tentatio) which takes place through an assault upon human beings (impugnatio) and is intended to put them to the test (probatio). This Anfechtung refers to both the objective assault of spiritual forces upon the believer, and the subjective anxiety and doubt that arise within us as a consequence of these assaults. However, when believers recognise God's merciful intention that underlies Anfechtung, they rejoice in such assaults seeing in them the means by which God indirectly effects and ensures our salvation. For this reason, Luther is able to refer to Anfechtung as a 'delicious despair' (McGrath ibid:171) and a vital ingredient in a theopaschitic interpretation of the cross.

Ngien (1995:175) concludes: '[T]he suffering of God has an 'ontological status' in Luther's theologia crucis.' The implication of Luther's theologia crucis on the traditional understanding that only the humanity of Christ suffers on the cross whilst Christ's divine nature is untouched, is that God indeed suffered in his Son. 'God suffers on the cross in oneness with the person of Jesus Christ who is ontologically constitutive of God' (Ngien ibid:175). So, for Luther, the Father suffers in compassion with the Son in the Spirit of love between them. In the light of God's expiatory suffering, the fundamental truth of the Christian faith consists in the fact that God, in the passion history of Jesus Christ, has suffered the curse of death, the misery of infinite suffering and, eventually, suffered them into defeat.

The essential theological point is that Christ's suffering cannot be separated from God's suffering. The motivation behind such a 'paschitic formula' is to link our human suffering to God's identification with our pain and misery.

Some of the most important proponents of theopaschitism in the 20th century were the following:

1. God's weakness (Bonhoeffer 1970). By his suffering, God shows that he is weak, vulnerable and powerless in this world. Only Christ's weakness can help us to resist suffering in an attitude of protest or resistance and surrender (Widerstand und Ergebung).

2. God's powerlessness (Sölle 1973). In her book, Leiden, Sölle objects to the sadistic image of God evident in traditional theodicy. She portrays Christ as God's representative who introduces himself as the One who suffers with humans. Wherever people suffer, there Christ suffers. God suffers particularly in the social and political dimensions of suffering. God justifies himself in political suffering. He remains powerless and is dependent on us to bring about change. As Christ's representatives, it is thus our task to eliminate social and political suffering.

3. God's being as an event of becoming (Gottes Sein ist im Werden; Jüngel 1967). God's revelation of himself is not complete. This does not mean that God himself is incomplete, but rather that God reveals himself as a Fürsich-sein [a Being for himself] who, in his grace, is also a Für-uns-sein [a Being for us]. In his capacity as a Being for us, God becomes involved in the suffering of humankind, and thus he becomes a suffering God for sinners in a dynamic act of revelation. In these events of 'God being for us', God's Being is still in the process of becoming (incomplete).

4. God's forsakenness (dereliction; Moltmann 1972). God's dynamic involvement in suffering is a Trinitarian event, the true character of which has been revealed by the cross. In the God-forsakenness of the cross (derelictio), God is the Ganz Andere [totally Other] who does not have to be justified by humankind. On the cross, God justifies himself as the One who pronounces justification on humankind. He does this by completely identifying himself with human suffering and displaying solidarity with human forsakenness.

5. God's defencelessness (Berkhof 1973; Wiersinga 1972). Wiersinga rejects the notion that suffering is punishment for sin. For him, there is no likelihood of God's justice being punitive or retaliatory. He contends that it can be discounted that God is the origin of suffering or that he wills suffering and has accommodated it in his providence. The only connection between God and suffering is that he himself suffers with us. Here God reveals himself as the defenceless God. According to Berkhof (ibid), God's defencelessness is the space that he has left for the freedom of human responsibility. Berkhof does not regard this defencelessness as mere powerlessness, but as a display of God's overwhelming love (power).

\section{Theologia crucis: The weakness (astheneia) of God in passion}

Whilst Luther's theology of the cross has a strong pastoral theme (God's relationship with humans in their suffering) and should primarily be assessed as an attempt to unmask the falsehood of a theologia gloria, Barth tries to indicate the reality of God's condescension as revealed in Christ's humiliation. In terms of a Barthian approach, a theologia crucis reveals the authenticity of God's condescension and thus 'proves' God's companionship and solidarity with our suffering through Christ, the Mediator. For Barth, suffering can indeed be linked to God in the sense that God took our distress upon himself.

God takes our distress upon himself. In the Redeemer, God as judge enters into our need. He is 'for us' (Barth 1953:236-362) in the condemned Christ (substitution). This 'being for us' is a deliberate action by Christ. It occurs only once in history and is an action by God performed in the Person, Jesus Christ. Thus, his suffering can be understood as 'Passion Gottes' (Barth ibid:270).

One of the most well-known theologians in the theologia crucis debate in the 20th century, and even still in the 21st century, is Jürgen Moltmann. 
A theology of the cross cuts through all dezification of human beings and all metaphysical abstractions of God (theism). It is thus a radical theology which aims at influencing theism with its abstract image of God. It is also secularised Christendom with its blind 'ungodliness'. The theology of the cross once again emphasises the solidarity of God in the midst of the history of suffering.

Moltmann's theology of the cross is based on the premise that if the suffering on the cross is in fact a Messianic suffering, then God himself is involved in the suffering. By this premise, Moltmann breaks away from Aristotle's metaphysical theistic view of God as being immovable, apathetic and unchanging. A theology of the cross means a radical change in Western Christianity's concept of God. The God-concept inspired by the Greeks is one of apathy, with immutability as a static-ontic category. In contrast, a theology of the cross is a 'pathetic theology' in which God's pathos, not his apatheia (Moltmann 1972:256), is emphasised. It is in pathos that God reveals himself in such a way that he becomes involved in loving solidarity with human suffering. An apathetic God moulds a human being into a homo apatheticus; a pathetic God moulds a human being into a homo sympatheticus.

In Jesus' resurrection, God is the God in action. In the crucifixion, he is the God in passion. The latter is not a static God, but a dynamic God who is actively involved in the Godforsaken cry of Christ on the cross: 'My God, my God, why have you forsaken me?' Jesus' cry from the cross (derelictio) outlines a Trinitarian theology of the cross. This cry defines God's 'how' in suffering. Therefore, in this sense (namely that suffering is indeed a mode of God's very being and his mediatory involvement in our pain God is indeed a divine identification with human impairment and weakness), this article opts for the notion of a 'disabled God'.

\section{Theologia resurrectionis: The abled God in action}

It is indeed true that tragedy forces theology to acknowledge the vulnerability of a suffering God (Schaab 2011:11-12). Is such a God-image, however, the only appropriate understanding of God? What about our human need for courage, strength, empowerment, change and transformation?

According to Moltmann, without the resurrection, God's identification with human suffering (even the cross) would be meaningless. The suffering on the cross becomes a source of hope for a suffering humanity only when it is seen in the light of Jesus' resurrection. This is what makes the theology of the cross essentially an eschatologia crucis.

The message of God's faithfulness is inextricably linked to the transformative reality of the cross and the victorious event, namely the resurrection. Being 'saved in hope' makes us more than conquerors. That God is indeed an 'abled God' is demonstrated by a theologia resurrectionis.

In Theologie des Neuen Testaments, Goppelt (1980:56) argued that the message of resurrection forms the heart and core of New Testament theology. From the perspective of the resurrection, the existing situation of the early church could be analysed in view of its transformation and its focus on the future. The resurrection message forms the basis of New Testament theology. In view of the central role of hope in theology, Guthrie (1981:389) asserts that ' $[t]$ he reality of the resurrection is, therefore, an indispensable basis for Christian hope in the future'. Resurrection and suffering are two themes that cannot exist separately.

In A theology of Auschwitz, Simon (1967) does not regard the resurrection as an easy way out of suffering and pain, but rather that the resurrection incorporates them into a new perspective on life. Resurrection faith does not retreat from the reality of suffering, but confirms the tragedy of suffering (Simon ibid:101). Since the resurrection is not only a new perspective, but also a historic reality, it has consequences for hope. Hope is actually resurrection hope (Moltmann 1966).

The implication of both a theopaschitic theology and a theology of the resurrection, is that it reframes our understanding of divine power. It proposes a paradigm shift from power as force (the pantokrator image) to power as steadfast faithfulness, compassionate encouragement and active hope. Theopaschitic theology revises a theology of Caesar-power into a theology of compassionate empowerment.

Fretheim's conclusion (1984) is remarkable:

For, even in those instances where the vestments of God's appearance are threaded with lineaments of power, they clothe in vulnerable form. There is no such thing for Israel as a nonincarnate God. (p. 106)

According to Häring (1986), God is not a pantokrator - neither should he be seen in terms of Aristotle's potentia. God's power is his redeeming vulnerability and powerlessness omnipotence is God's loving invitation 'to a relationship and covenant encounter which guarantees real freedom'.

According to Van de Beek (1984:91-92), behind the concept omnipotence lies the motive to see God as the absolute One - the Super King with a driving force (despotes). Behind every event God functions as the prima causa. Van de Beek is convinced that more fundamental than Berkhof's 'weerloze overmacht', is the overwhelming phenomenon of God's majestic highness and splendid glory. God's dominion and sovereignty exist in the interest of humankind. His aim is to conquer the evil powers of sin and darkness.

\section{The theological praxis of ta splanchna}

It is the author's contention that the passio dei is an exposition of the praxis concept of ta splanchna. The latter is related to the Hebrew root rhm [to have compassion]. It is used in close connection to the root hnn which means 'to be gracious'. Together with oiktirmos and hesed it expresses the being quality of God as connected to human vulnerability and suffering (Esser 1976:598). The verb splanchnizomai is used to make the unbounded mercy of God visible. 
Within metaphoric speech, ta splanchna expresses pity, compassion and love. 'The oldest form of the verb is splanchneuō, eat the entrails, prophesy from the entrails' (Esser 1976:599). Within the messianic context of Christ's salvific mission, ta splanchna expresses compassion as an indication of God's divine involvement with the human predicament of suffering.

It is interesting to note the cases where Christ responded to human suffering with the contraction of the entrails, expressing messianic compassion. For example, the leper with his petition (Mk 1:41), the people like sheep without a shepherd (Mk 6:34), the sight of the harassed and exhausted crowd (Mt 9:36), the two blind men who besought him (Mt 20:34) and the widow at Nain, mourning her only son (Lk 7:13). In Luke 15:11-32 (the parable of the prodigal son), splanchnizomai expresses the strongest feeling of a merciful and loving reaction (verse 20). In the parable of the Good Samaritan (Lk 10:33), splanchnizomai expresses the attitude of complete willingness to use all means, time, strength and life for saving at the crucial moment (Esser 1976:600).

Ta splanchna reveals God as a Presence, 'a Companion, "your God"'(Hall 1993:147). The ta splanchna texts totally reframe our understanding of who God is and what is meant by God's power which is now understood as passion and compassion. Not in the mode of Ceasar-like power, but the 'fortigenetics', resilience or existential boldness of an eschatological understanding of hope: 'Against all hope, Abraham in hope believed' (Rm 4: 18).

If ta splanchna displays the seriousness of God's 'being with' and 'being within', bowel categories reveal the ontological seriousness and vulnerability of God's faithfulness. It demonstrates what Reynolds (2008:123) calls the moral fabric of love: availability'. Bowel categories then indicate the integrity and sincerity of God in suffering. Bowel categories also display a Divine 'being with' which make it possible for the metaphor of 'the puffing God in the wheelchair' (Reynolds ibid) - a compassionate mode ${ }^{1}$ of hopeful 'being with within' despite a wheelchair.

'Together, people with disabilities and the able-bodied, must be reconciled with the disabled God through Jesus Christ's broken body in Eucharistic repentance and celebration' (Eiesland 1994:25).

\section{Conclusion}

Asthenaia refers to all forms of human sickness, ailments, diseases, disabilities and general human weakness in the Bible. The cross of Christ could be viewed as an icon of the disabled God. In terms of metaphoric speech, one can say that in the sigh and derelictio cry of the suffering and dying Christ, one hears the sigh and 'puffing' of disabled people.

1 .In the posture of compassion I am brought to resist dehumanising powers and defend the refusal or abuse of another's vulnerable face, making his or her cause my own. Thus compassion signifies a mutual relation of vulnerability that exists beyond condition established by the status quo' (Reynolds 2008:128).

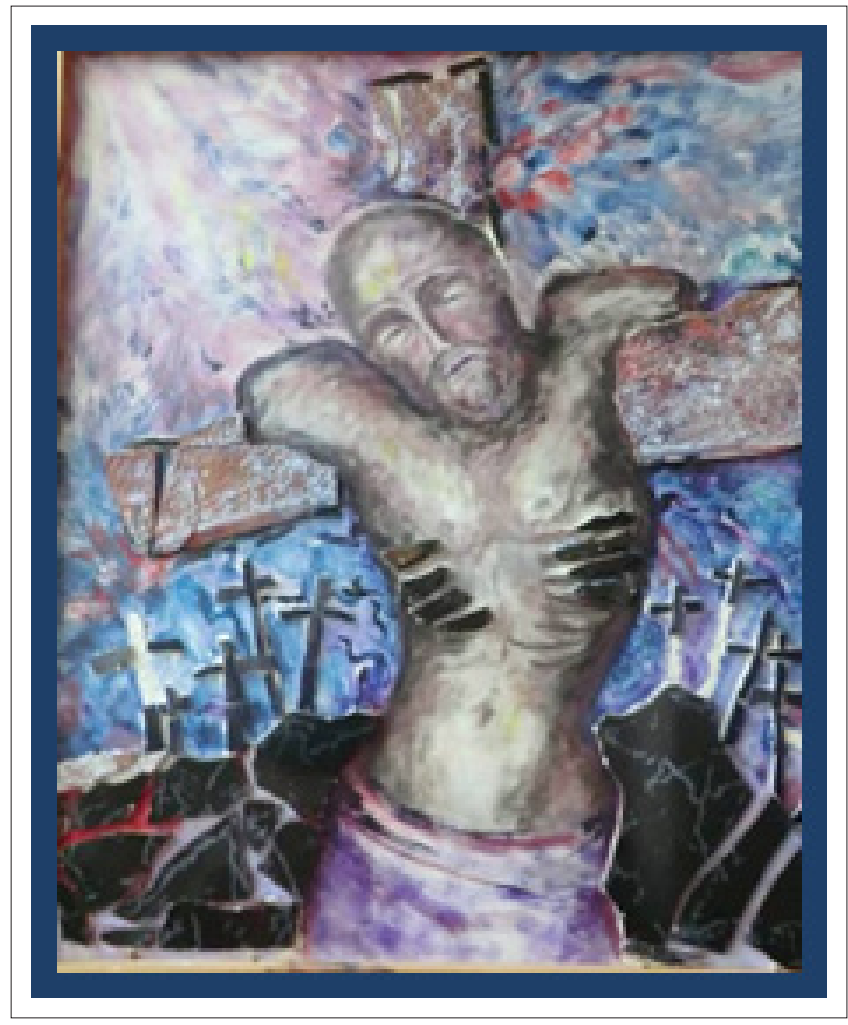

Source: Louw, D.J., 2013, The disabled God, Chapel, University of Stellenbosch, Stellenbosch FIGURE 1: The disabled God.

God is indeed becoming, in the disfigurement of the crucified Christ, the disabled figure - 'puffing in his wheelchair'.

This painting depicts the 'suffering God' within the realm of death. The many crosses in the background refer to the many deaths of martyrs and undeserved suffering. The disabled body presents God's identification with human disfigurement.

The suffering and dying God within a theologia crucis demonstrates the reality of an inclusive compassion of replacement: to carry the burden of woundedness on behalf of the other. 'Compassion signifies participative connection, what we might call sympathetic attunement' (Reynolds 2008:126).

Disability is not a fault, mistake or tragedy that must be overcome by the individual with a kind of curative medical model (Reynolds 2008:30). Disability is a reality of our being human within the vulnerability of life. With regard to a theology of the intestines, disabilities should be embraced as part of an affirmed being. Within a theologia resurrectionis, all forms of stigmatisation should be deleted due to the fact that resurrection makes us resistant to the death of discrimination (die opstandigheid van die opstanding). Bowel categories designate hope as a new state of being beyond the limitations of disabled categories. It describes a spiritual ability within the new reality of parrhesia categories: the boldness of a 'courage to be' and the vividness of a hope that can transcend the boundaries of all forms of human limitations and disfigurement. 


\section{Acknowledgements Competing interests}

The author declares that he has no financial or personal relationship(s) that may have inappropriately influenced him in writing this article.

\section{References}

Barth, K., 1953, Die Lehre von der Versöhnung, EVZ, Zollikon/Zürich. (Die Kirchliche Dogmatik IV/1; IV/3)

Berkhof, H., 1973, Christelijk geloof, Callenbach, Nijkerk.

Bonhoeffer D., 1970, Widerstand und Ergebung: Briefe und Aufzeichnungen aus der Haft, Kaiser, München.

Claassens, J., Swartz, L. \& Hansen, L., 2013, Searching for dignity: Conversation on human dignity, theology and disability, Sun Media, Stellenbosch.

Coetzee, T., 2011, "n Nuwe geur vir Oscar', Rapport, My Tyd, 01 Mei, pp. 8-10.

Davies, O., 2003, A theology of compassion: Metaphysics of difference and the renewal of tradition, Eerdmans, Grand Rapids.

Eiesland, N.L., 1994, The disabled God. Toward a liberatory theology of disability, Abingdon Press, Nashville.

Esser, H.-H., 1976, 'Splanchna', in C. Brown (ed.), Dictionary of New Testament Theology, Paternoster Press, Exeter, vol. 2, pp. 599-601.

Feitsma, M., 1956, Het theopaschitisme: Een dogma-historische studie over de ontwikkeling van het theopaschitisch denken, Kok, Kampen.

Fretheim, T.E., 1984, The suffering of God, Fortress, Philadelphia.

Gaventa, B., 2012, 'Spiritual/pastoral care with people with disabilities and their families', in R.S.B. Robberts (ed.), Professional and spiritual pastoral care. A practical clergy in R.S.B. Robberts (ed.), Professional and spiritual pastoral care. A practical cler
and chaplain's handbook, pp. 291-302, Skylight Paths Publishing, Woodstock.

Goppelt, L., 1980, Theologie des Neuen Testaments, 3rd edn., Vandenhoeck and Ruprecht, Göttingen.

Guthrie, D., 1981, New Testament Theology, InterVarsity, Leicester.

Hall, D., 1993, Professing the faith. Christian theology in a North American context, Fortress Press, Minneapolis.

Häring, H., 1986, 'Het kwaad als vraag naar Gods macht en machteloosheid', Tijdschrift voor Theologie 26(4), 351-372.

Hick, J., 1966, Evil and the God of love, Harper \& Row, New York.

Inbody, T., 1997, The transforming God: An interpretation of suffering and evil, Westminster John Knox Press, Louisville, Kentucky.

Jüngel, E., 1967, Gottes Sein ist im Werden, 2nd edn., JCB/Paul Siebeck/Mohr, Tübingen.

Kool, J., 2002, Goed bedoeld. Levensbeschouwelijk kijken naar handicap en ziekte, Boekencentrum, Zoetermeer.

Knights, W.A. (Jr.) \& Koenig, H.G., 2001, Pastoral counseling. A Gestalt approach, The Haworth Pastoral Press, New York.
Leech, K., 1985, Experiencing God: Theology as spirituality, Harper \& Row, New York. Leech, K., 1986, Spirituality and pastoral care, Sheldon, London.

Louw, D.J., 2000, Meaning in suffering. A theological reflection on the cross and the resurrection for pastoral care and counselling, Peter Lang, Frankfurt.

Louw, D.J., 2008, Cura vitae. Illness and the healing of Life, Lux Verbi, Wellington.

Louw, D.J., 2012, Network of the human soul. On identity, dignity, maturity and life skills, Sun Press, Stellenbosch.

Louw, D.J., 2013, The disabled God, Chapel, University of Stellenbosch, Stellenbosch. Luther, M., 1518, Disputatio Heidelbergae habita. (Die Weimarer Ausgabe I).

McGrath, A.E., 1985, Luther's theology of the cross: Martin Luther's theological breakthrough, Blackwell, Oxford.

Miller-McLemore, B.J., 2006, 'Wisdom in pastoral care and counseling: What does it entail?', Pastoral Psychology 55 (2) Nov 2006, 217-222. http://dx.doi.org/10.1007/ s11089-006-0037-y

Moltmann, J., 1966, Theologie der Hoffnung: Untersuchungen zur Begründung und zu den Konsequenzen einer christlichen Eschatologie, 5th edn., Kaiser, München.

Moltmann, J., 1972, Der gekreuzigte Gott, Kaiser, München.

Nauer, D., 2010, Seelsorge. Sorge um die Seele, Kohlhammer, Stuttgart.

Ngien, D., 1995, The suffering of God according to Martin Luther's 'Theologia Crucis', Peter Lang, New York. (Series VII Theology and Religion, vol. 181)

Pasewark, K.A., 1993, A theology of power. Being beyond domination, Fortress Press, Minneapolis.

Psalter Hymnal, 1959, Psalter Hymnal. Doctrinal standards and liturgy of the Christian Reformed church, Publication Committee of the Christian Reformed Church, Grand Rapids.

Reynolds, T.E., 2008, Vulnerable communion. A theology of disability and hospitality, Brazos Press, Grand Rapids.

Robinson, J.A.T., 1963, Honest to God, SCM Press, London.

Saunders, C., 2010, 'Why spirituality in palliative care?' in C.M. Puchlaski \& B. Ferrell (eds.), Making health care whole. Integrating spirituality into patient care, $\mathrm{pp}$ 3-16, Templeton Press, West Conshohocken.

Schaab, G.L., 2011, The creative suffering of the triune God. An evolutionary theology, Oxford University Press, Oxford.

Schipani, D.S., 2003, The way of wisdom in pastoral counseling, Institute of Mennonite Studies, Elkhardt.

Simon, U.E., 1967, A theology of Auschwitz, Gollancz, London.

Sölle, D., 1973, Leiden, Kreuz, Stuttgart.

Sperry, L., 2002, Transforming self and community. Revisioning pastoral counselling and spiritual direction, The Liturgical Press, Collegeville.

Van de Beek, A., 1984, Waarom? Over lijden, schuld en God, Callembach, Nijkerk.

Von Loewenich, W., 1976, Luther's theology of the cross, Christian Journals Limited, Belfast.

Wiersinga, H., 1972, Verzoening als verandering, Bosch \& Keuning, Baarn.

Wong, P.T.P., 2012, The human quest for meaning. Theories, research, and applications, Routledge, New York. 